\title{
ASSESSMENT OF THE SOUTHERN URALS RECREATIONAL POTENTIAL FOR THE DEVELOPMENT OF THE AKTOBE TOURISM INDUSTRY
}

\author{
Zharas BERDENOV* \\ L.N. Gumilyov Eurasian National University, Faculty of Natural Sciences, Nur-Sultan, Republic of Kazakhstan, e-mail: berdenov-z@mail.ru \\ Erbolat MENDYBAYEV \\ K. Zhubanova Aktobe Regional State University, Department of Ecology, Alia Moldagulova, Aktobe, Kazakhstan, e-mail: beskurek@mail.ru
}

\author{
Aidana BEKETOVA
}

L.N. Gumilyov Eurasian National University, Faculty of Natural Sciences, Nur-Sultan, Republic of Kazakhstan, e-mail: atbeketova@mail.ru

$$
\text { Nuriya SATKAROVA }
$$

L.N. Gumilyov Eurasian National University, Faculty of Natural Sciences, Nur-Sultan, Republic of Kazakhstan, e-mail: nsatkarova@gmail.com

\author{
Maria GOZNER
}

University of Oradea, Department of Geography, Tourism and Territorial Planning, Romania, e-mail: mariagozner@yahoo.com

\begin{abstract}
Citation: Berdenov, Z., Mendybayev, E., Beketova, A., Satkarova, N., \& Gozner, M. (2021). ASSESSMENT OF THE SOUTHERN URALS RECREATIONAL POTENTIAL FOR THE DEVELOPMENT OF THE AKTOBE TOURISM INDUSTRY. GeoJournal of Tourism and Geosites, 38(4), 1274-1279. https://doi.org/10.30892/gtg.38435-769
\end{abstract}

\begin{abstract}
Tourism is a sphere of the social and economic complex, which is gradually turning into a developing industry. The importance of tourism development for the economy of Kazakhstan as a whole is essential. This scientific article is devoted to the assessment of the promising areas recreational potential of the Aktobe regions tourist activity. The study geographically describes the research area, the pattern of natural and climatic conditions, the uniqueness of landscapes and the complexity of their spatial and temporal organization. The units of physical-geographical or economic-geographical zoning serve as an objective basis for assessing territorial combinations of natural conditions and resources. The scientific work gives a brief description of the natural conditions, geomorphological and floral composition of the Southern Urals territories that are promising for recreational tourism. The article presents the factors reflecting the attractiveness of the region for the creation of specially protected natural areas.
\end{abstract}

Key words: potential, recreation, tourism, ecological and recreational potential

\section{INTRODUCTION}

Health tourism, potential in various literature is interpreted as a set, power, opportunity, productivity, prerequisites. Potential is a collection of available means and opportunities in any area. It is not what has been revealed, but what is in a hidden form can be manifested under certain conditions (Isachenko, 2008; Dunets, 2019). The recreational potential of a territory is a combination of natural, cultural-historical, economic-geographical, social, and economic prerequisites for the organization of recreational activities. The main components of the recreational potential are natural and recreational resources. Recreational potential can be assessed at the world, country, region, etc. levels (Akhmedenov et al., 2017; Egorina, 2016; Erdavletov, 2010). The territory has a potential, which expressed in the combination of resources and conditions for its development in various branches of economic activity. Potential opportunities of the territory are implemented through social needs, which manifest themselves in the form of various types of nature management. The variety of types of nature management in a certain territory depends on its resource availability and the conditions for their development, the structure and nature of social needs, the types of existing social needs and the size of the territory (Berdenov, 2016; Beketova, 2019; Akhmedenov, 2020). Therefore, we can talk about the multiplicity of potentials of the territory, which appears itself in a variety of forms of nature management. In this regard, the recreational potential is one of the types of potential opportunities for the territory use. Sometimes recreational potential is called the ratio between the actual and maximum possible number of tourists, determined based on the availability of recreational resources. Very often, some understand the recreational potential as the presence of certain unique or, at least, interesting not only for local residents objects (Suleimenov, 2021; Datta, 2020).

Many domestic and foreign scientists studied the issues of assessing the natural potential of the territory for the purposes of tourism development. Various methodological approaches to assessing the natural and recreational potential of the territory are acquainted in the scientific works of R.S. Yerdavletov and etc. (Erdavletov, 2010; Ilies, 2010; Suleimenov, 2020; Dunets, 2020; Page, 2011). Recreational potential characterizes the extent to which the territory is able to meet the needs of the population in recreational activities. Assessment of recreational potential is subjective, variable in space and time (Carretero, 2014; Khomitch, 2019). Recreational assessment of the territory is necessary primarily for information support of environmental management in order to increase its ecological and economic efficiency and the development of tourism in the region (Jackson, 2002; Berdenov, 2015; Ilies, 2017; Herman, 2019; Deac et al., 2019; Indrie et al., 2020; Marcu et al., 2020). 


\section{MATERIALS AND METHODS}

The factors that reflecting its value characteristics are considered as criteria for assessing the recreational potential. These factors are landscape and cultural and landscape value of the area (historical, cultural, landscape and architectural), the degree and pattern of the development of the territory, the presence of protected areas, the availability of conditions for recreation, educational tourism and other types of recreation. In this research, several general approaches to the assessment of recreational resources are merged and evaluated primarily by:

- their functional suitability for a particular type of ecological tourism (technological assessment);

- degree of comfort (physiological assessment);

- aesthetic qualities (psychological assessment) (Erdavletov, 2010; Nazarova, 2019; Sokolova, 2004).

The approach includes the implementation of assessment of any resource by factor-by-factor basis, summing up the obtained values, and display of the average assessment of the correspondence of a given object to a particular type of tourism.

In process of analyzing the resource base, we used a three-point rating scale, where factors are assessed as favorable for the development of a particular type of tourism ( 3 points), relatively favorable ( 2 points) and unfavorable (1 point).

To assess the recreational potential, an analysis of field expedition research (May-August 2019-2020), a generalization of stock materials, an excursion and field method of collecting information, as well as modeling and factor-by-factor assessment methods were carried. The results of the analysis led to creation of a geographic database by blocks in the ArcGIS 10.1 software. The study area is located in the Aktobe region, Kargalinsky district, on the Southern spurs of the Ural Mountains, near the Kargalinsky reservoir $\left(50^{\circ} 6^{\prime} \mathrm{N} ; 57^{\circ} 7^{\prime} \mathrm{E}\right)$ (Figure 1 , map and image of the area).

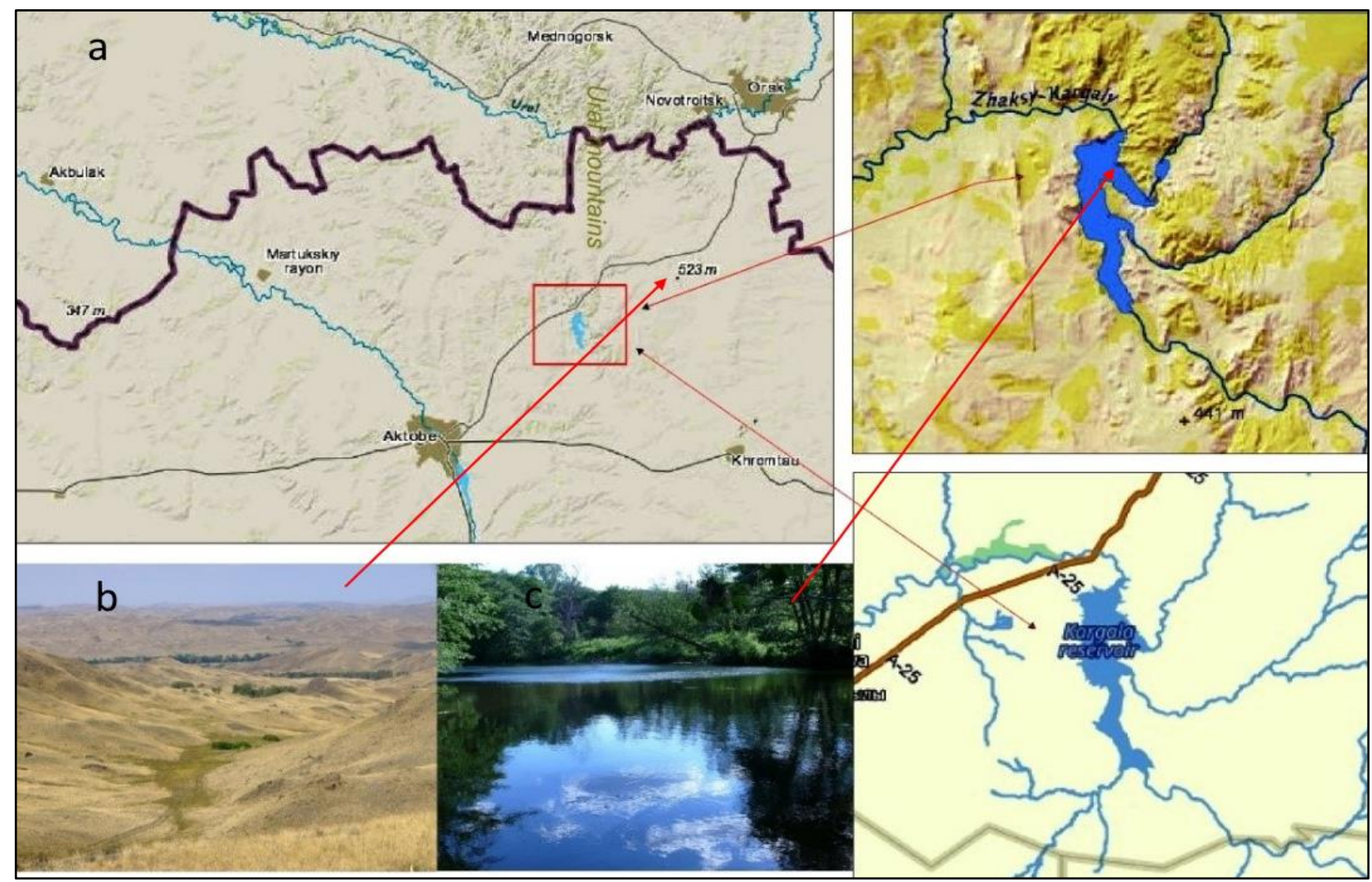

Figure 1. Study area: a - Map created by the author in the ArcGIS; b - Photo by the author from the high-altitude point of the Southern Urals, near the reservoir; c - Photo by the author of the north-eastern part of the Kargala reservoir

Geological structure. The research area belongs to the area of the Or-Ilek interfluve. Sedimentary, volcanogenic, metamorphic strata of the Proterozoic and Paleozoic, as well as Pre-Paleozoic, Caledonian and Hercynian rocks compose the interfluve. This is a low-waving small-mound dissected by a dense network of valleys of temporary watercourses. The relief depressions accumulate quaternary and modern loose accumulative deposits (Vilesov, 2009).

Surface waters: The Kargalinsky reservoir is located $60 \mathrm{~km}$ northeast of Aktobe, in the upper reaches of the ZhaksyKargaly river. The dam is built in the rocks. The total volume of water is 186 million $\mathrm{m}^{3}$. The reservoir has been in operation since 1975 . Water releases are carried out around the clock from $2-3 \mathrm{~m}^{3} / \mathrm{s}$ in autumn and winter to $8-12 \mathrm{~m}^{3} / \mathrm{s}$ in summer.

\section{RESULTS DISCUSSIONS}

Recreational zoning is the division of territory according to homogeneous characteristics and the nature of recreational use, reflecting territorial differences in the interaction of society and nature. In the study of recreational potential, the organization of protected areas in zones where no unchanged steppe natural landscapes preserved is important. Today, agricultural development of the territory has led to the highest degree of landscape degradation in comparison with other zones. Agricultural fields with cultivated crops, hayfields and pastures replaced primal natural landscapes. 
In order to maintain ecological balance and a regulated regime of nature use, it has already been proposed more than once to create a network of specially protected natural territories (Berdenov, 2016; Beketova, 2019). We assume that the most promising area in the Aktobe region would be the foothill part of the Ural Mountains, where pristine nature is currently preserved. The location of large bodies of water (lakes, rivers, reservoirs), which can be considered as a transit route for migrating birds, play particular importance. An assessment of the recreational potential was conducted to determine the possibilities of the territory in the development of recreation. The assessment of recreational resources was carried out according to several blocks of parameters (Berdenov, 2018) (Table 1). These parameters are different for the main types of recreational activities. Such assessment was carried out based on the physical and geographical conditions of territory, climatic factors and the recreational possibilities of landscapes.

Table 1. Assessment of recreational potential in near the Kargalinsky reservoir (Kuskov, 2005)

\begin{tabular}{|l|c|}
\hline \multicolumn{1}{|c|}{ Factor } & Scale (points) \\
\hline 1. Assessment of the natural landscape potential for the development of various types of tourism (total for the block) & $\mathbf{2 . 7 5}$ \\
\hline 1.1 Terrain & 3 \\
\hline 1.2 Water bodies & 3 \\
\hline 1.3 Soil and vegetation cover & 3 \\
\hline 1.4 Bioclimate & 2 \\
\hline 2. Recreational assessment of historical and cultural monuments & $\mathbf{1 . 5}$ \\
\hline 3. Tourist infrastructure (total for the block) & $\mathbf{2}$ \\
\hline 3.1 transport support & 2 \\
\hline 3.2 telecommunications & 3 \\
\hline 3.3 accommodation and catering & 2 \\
\hline 3.4 information support & 1 \\
\hline Total block average & $\mathbf{2 . 1}$ \\
\hline
\end{tabular}

1.1 In evaluating the relief for recreational tourism, we took into account the dissection degree of the terrain: the dissection density, depth and slope steepness. The relief near the Kargalinsky reservoir is elevated riverine hills with sections of plains and plateaus with absolute elevations from $300 \mathrm{~m}$ to $400 \mathrm{~m}$. The territory is rugged by river valleys and temporary watercourses valleys. Ravines cut thought flat plain slopes. The shores of the reservoir are steep and gentle, high and low with bays and coves (Figure 2). All terrain characteristics must be taken into account for laying hiking trails. For recreational purposes, the most favorable is a large hilly or ridge relief, which is characteristic in the northern and northwestern parts of the study area; relatively favorable slightly hilly and undulating terrain is typical in the eastern part of the territory. Moreover, the relief near the reservoir is favorable for the development of sports tourism, active forms of ecotourism and extreme tourism, where the presence of obstacles (mountainous terrain, ravines, steep river banks) were taken into account. Another important value is the development of scientific, educational and eco-tourism tour that reveals the presence of rare and attractive forms of morphological structure - tectonic faults, marine terraces, etc. In connection with these indicators, according to paragraph 1.1, we have set a maximum score of 3 .
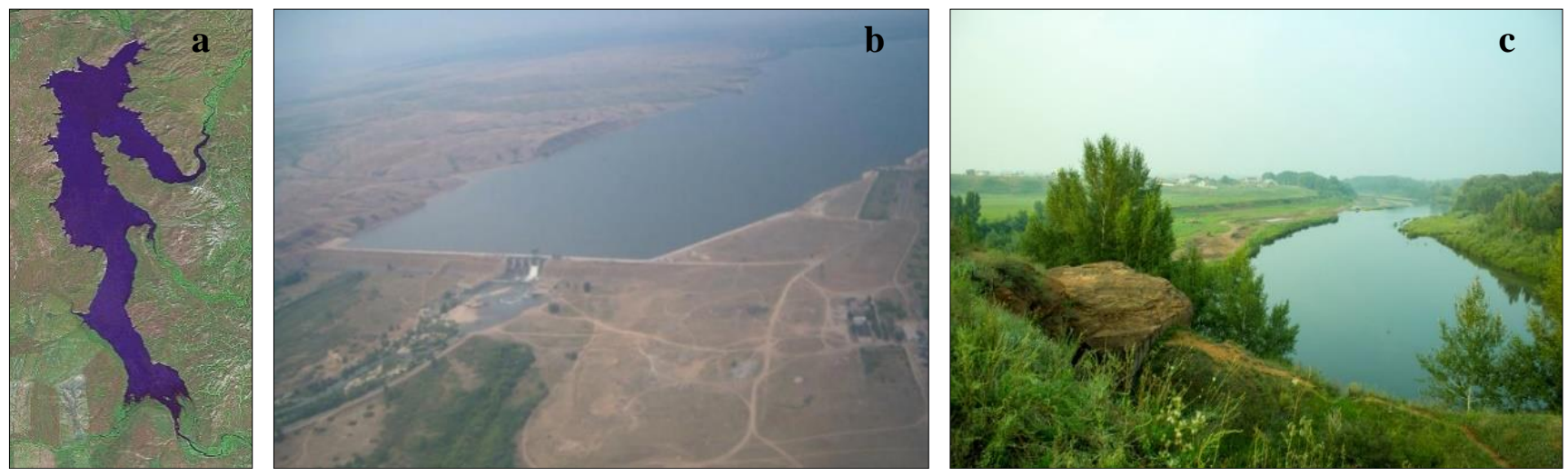

Figure 2. Relief of the vicinity of the Kargalinsky reservoir a-satellite image from the

SasPlatnet program**; b-aerial image of the northern part of the reservoir**; c-photo by the author, southern edge of the reservoir

1.2 The assessment of water objects for cultural recreation was also estimated at 3 points. Because the basis of the following indicators: the nature of the shore, approaches to the water, the nature of bathing places, the coastal shoal and bottom, the flow velocity (for the rivers Zhaksa Kargala, Ebita, Kos-Expired), water temperature (in the summer, bathing season) and environmental conditions carried out the assessment. The degree of pollution, the speed of the river flow, the length of the route, the looping of the route, and transport accessibility were taken into account when assessing reservoirs and watercourses for active family tourism. At the same time, the most favorable for recreation were the eastern part of the Kargalinsky reservoir and the Zhaksy Kargaly River (where the WPI is close to 1). In order to determine «Water pollution index» (WPI), we took water samples in the spring, summer and autumn seasons for the chemical analysis of the constituent microelements (Table 2).

1.3 Assessment of the soil and vegetation cover is the most important in determining the prospects for the recreational tourism development in the studied area. When assessing soils, primarily we considered the types of soils and the humus 
content. In order to do it, we laid four soil pits near the reservoir and took samples from various genetic horizons to determine the content of trace elements. Sampling was accompanied by descriptions of the soil profile morphology.

The feather-grass-white wormwood association Stipa capillata, Artemisia lerchiana, on dark chestnut soils with alternating birch and aspen groves along the coastal areas represent the soil cover. The soil-forming rocks are clay and heavy-loamy quaternary deposits. They are eluvium of various rocks, processed by water and wind. Sandy-gravel alluvial and delluvial loams and, very rarely, sandy loams compose the soil-forming rocks in the elevated parts of the study area The thickness of the soil-forming rocks within the district is small and ranges from $20-60 \mathrm{~cm}$.

Table 2. Water pollution index (WPI) calculation of waters from selected samples for 2020 (own chemical analysis)

\begin{tabular}{|c|c|c|c|c|c|}
\hline № & Sampling site name & WPI & $\begin{array}{l}\text { Composition and } \\
\text { indicators of water quality }\end{array}$ & $\begin{array}{c}\text { Average } \\
\text { concentration, } \\
\text { mg } \backslash 1\end{array}$ & $\begin{array}{l}\text { The multiplicity of } \\
\text { exceeding the MPC }\end{array}$ \\
\hline \multirow{6}{*}{1} & \multirow{6}{*}{$\begin{array}{l}\text { Kargalinskoe reservoir in the } \\
\text { eastern part, close to the A- } 25 \\
\text { motorway }\end{array}$} & \multirow{6}{*}{1,04} & $\mathrm{BOD}_{5}$ & 1.0 & 0.58 \\
\hline & & & $\mathrm{O}_{2}$ & 11.44 & 0.52 \\
\hline & & & $\mathrm{N}_{2}$ & 0.06 & 3.00 \\
\hline & & & $\mathrm{Fe}$ & 0.18 & 1.80 \\
\hline & & & Ammonium ions & 2.02 & 4.04 \\
\hline & & & Phenols & 0.001 & 1.00 \\
\hline \multirow{6}{*}{2} & \multirow{6}{*}{$\begin{array}{l}\text { Zhaksy Kargala river, along the } \\
\text { A- } 25 \text { motorway }\end{array}$} & \multirow{6}{*}{1,20} & $\mathrm{BOD}_{5}$ & 0.93 & 0.31 \\
\hline & & & $\mathrm{O}_{2}$ & 11.71 & 0.51 \\
\hline & & & $\mathrm{N}_{2}$ & 0.04 & 2.00 \\
\hline & & & $\mathrm{Fe}$ & 0.03 & 0.30 \\
\hline & & & Ammonium ions & 3.05 & 6.10 \\
\hline & & & $\mathrm{Cu}$ & 0.002 & 2.00 \\
\hline
\end{tabular}

Chemical analyses of selected soil samples from each horizon were determined according to GOST standards in the laboratory of Aliya and $\mathrm{KO}$ in the city of Aktobe.Determination of the content of trace elements in soils was carried out by the method of atomic absorption spectrophotometry in the laboratory of the RSE "Kazhydromet" in Aktobe city. The results of chemical analyzes are shown in Table 3.

Table 3. Composition of the dark chestnut soils water extract of the Kargalinsky region in 2020 (own chemical analysis)

\begin{tabular}{|c|c|c|c|c|c|c|c|c|c|c|}
\hline \multirow{2}{*}{ № } & \multirow{2}{*}{$\begin{array}{c}\text { Genetic } \\
\text { Horizon } \mathbf{c m}\end{array}$} & \multirow{2}{*}{ Humus } & \multirow[b]{2}{*}{ pH } & \multicolumn{4}{|c|}{ Anions mg-eq/1 \% } & \multicolumn{3}{|c|}{ Cations mg-eq/l \% } \\
\hline & & & & $\mathrm{CO}_{2}$ & $\mathrm{HCO}^{3-}$ & $\mathrm{Cl}^{-}$ & $\mathrm{SO}_{4}{ }^{2-}$ & $\mathrm{Ca}^{2+}$ & $\mathrm{Mg}^{2+}$ & $\mathrm{Na}^{+}$ \\
\hline 1 & A $0-25$ & 4.5 & 7.4 & Not found & $\begin{array}{c}0.50 \\
0.003 \%\end{array}$ & $\begin{array}{c}1.4 \\
0.05 \%\end{array}$ & $\begin{array}{c}0.053 \\
0.003 \%\end{array}$ & $\begin{array}{c}0.25 \\
0.005 \%\end{array}$ & $\begin{array}{c}0.08 \\
0.001 \%\end{array}$ & - \\
\hline 2 & B $25-45$ & 3.7 & 7.3 & Not found & $\begin{array}{c}0.521 \\
0.032 \% \\
\end{array}$ & $\begin{array}{c}1.2 \\
0.04 \% \\
\end{array}$ & $\begin{array}{c}0.17 \\
0.008 \% \\
\end{array}$ & $\begin{array}{c}0.13 \\
0.0025 \\
\end{array}$ & $\begin{array}{c}2.25 \\
0.027 \%\end{array}$ & - \\
\hline 3 & BC $45-65$ & 2.0 & 7.5 & $\begin{array}{c}\text { small } \\
\text { presence }\end{array}$ & $\begin{array}{c}0.44 \\
0.033 \%\end{array}$ & $\begin{array}{c}1.8 \\
0.06 \%\end{array}$ & $\begin{array}{c}0.027 \\
0.0013 \%\end{array}$ & $\begin{array}{c}0.75 \\
0.015 \%\end{array}$ & $\begin{array}{c}1.75 \\
0.002 \%\end{array}$ & - \\
\hline
\end{tabular}

The importance of vegetation cover as a recreational resource is very great for all types of natural tourism. Since it is associated with the health-improving effect of the landscape due to the ionization and phytoncidal properties of plants, the presence of attracting plant and animal species. An essential characteristic for determining promising types of tourism is the ratio of arable land, pastures and forests. However, since the studied territory is not large with a predominance of hilly terrain, wooded areas and the transition to pastures prevail accordingly. When assessing the vegetation cover for all types of commercial tourism (picking mushrooms, berries, medicinal plants), we took into account the species diversity of plants, their abundance, the presence of rare species and seasonality. Due to the above facts, the total score is 3 points.

1.4 An assessment of the bioclimate is necessary in order to predict the success of tourism development in a particular area. Bioclimate is the effect of climate on the human body. The assessment of the bioclimate is of interest for determining the prospects for the development of almost all types of recreational, sports, educational and natural tourism. Primarily because in the conditions of Western Kazakhstan the weather limits many types of tourist activity and determines its seasonal nature. The bioclimate analysis uses the same method of systemic, factor-integral assessment as landscape characteristics. The following factors: solar radiation regime, atmospheric circulation, wind regime, thermal regime are the main factors in assessing the bioclimate. The climate of the area is sharply continental: the average temperature of January is $17-19{ }^{\circ} \mathrm{C}$, July is $+20+21{ }^{0} \mathrm{C}$, and the average annual air temperature is $+1+2{ }^{0} \mathrm{C}$. Precipitation is $280-300 \mathrm{~mm}$, the duration of the frost-free period is 130-150 days, and the hydrothermal coefficient is $0.8-1.0$. The humidification coefficient is $0.40-0.50$. The average annual wind speed is $4.5-5.5 \mathrm{~m} / \mathrm{s}$; the prevailing winds of the northwest direction***.

All bioclimatic parameters are evaluated according to the degree of favorability on the human body. Studies have shown that the researched area in the summer has a beneficial effect on human organism. Simultaneously, a sharply continental climate causes the unfavorable factors that exert an increased load on the human body.

Various meteorological services provided statistical data of over past 10 years for researching the bioclimat of the region. The study took following indicators in assessing:

- solar radiation regime - the number of hours of sunshine per year, the number of days without sun per year, the characteristics of ultraviolet radiation;

- atmospheric circulation - the frequency of cyclones of weather, the frequency of contrasting weather changes;

- wind regime - the degree of wind load; 
thermal regime - the duration of the frost-free period, the duration of the bathing season, the duration of the periods of winter and summer recreation;

- humidity and precipitation regime - the duration of the occurrence of stable snow cover, the frequency of rainy weather (Vilesov, 2008). Consequently, analyzing all the factors the final score is 2.

After conducting an average statistical analysis on the sub-items of the block "Assessment of natural landscape potential for the development of various types of tourism", the final score is 2.75 .

2. Historical and cultural potential is the basis of educational tourism (Sokolova, 2004). It is represented by various types of architectural monuments (monuments of cult and secular architecture, etc.), archaeological and ethnographic monuments, folk crafts, scientific and technical complexes and structures. In this block, a score of 1.5 can be given, because there are monuments and holy places of local importance (aulie, burial places of local folk healers), which directly impart the development of historical and cultural potential.

3. The infrastructure block is subdivided into the following items: transport support; communal systems; telecommunications, accommodation and catering facilities. Its peculiarity lies in the fact that it simultaneously serves tourists and the local population. Therefore, its development contributes to the tourist development of the territory and improves the living conditions of the inhabitants of this region. Moreover, the tourist infrastructure creates a large number of jobs. Each component of the tourist infrastructure has its own evaluation criteria.

3.1. Transport service. A large highway A-25 of international importance is located near the investigated region, which connects two large industrial centers along the Aktobe-Orsk highway. A dense network of republican and local roads, a level of rolling stock, environmental friendliness and infrastructure also characterize the area. Transport service is rated 2 points.

3.2. The communication system includes: postal and telegraph communication, telephone communication, emergency call communication along highways, designed to meet the needs of the population and tourists in the prompt transmission of messages to special services (ambulance, service stations) in emergency cases and, if necessary, to communicate with subscribers of the telephone network. Beeline and Active cellular networks have excellent coverage near the Kargalinsky reservoir, since settlements of regional significance are located no more than $10 \mathrm{~km}$ in diameter.

3.3. Places of accommodation and food are determined by the development of food outlets in the study area: canteens, cafes, bistros, taverns, etc. This takes into account the total number of food outlets, the total number of seats, the uniformity of their placement on the territory of the region, the presence of food outlets near tourist centers and enterprises along highways and railways, rural areas located on tourist routes, technical equipment of food outlets. On a par to with previous factors, the level of services offered: variety of dishes, preparation of traditional dishes of local cuisine, availability of dishes from organic products and wild plants is one of the essential elements. According to the analysis of the territory under point 3.3 (according to table 1), it is given a score of 2. Because the territory under study is located in close proximity to the locality of S. Kosistek, S. Shamshi Kaldayakova (Figure 3), where there are directly catering outlets, shops, etc.
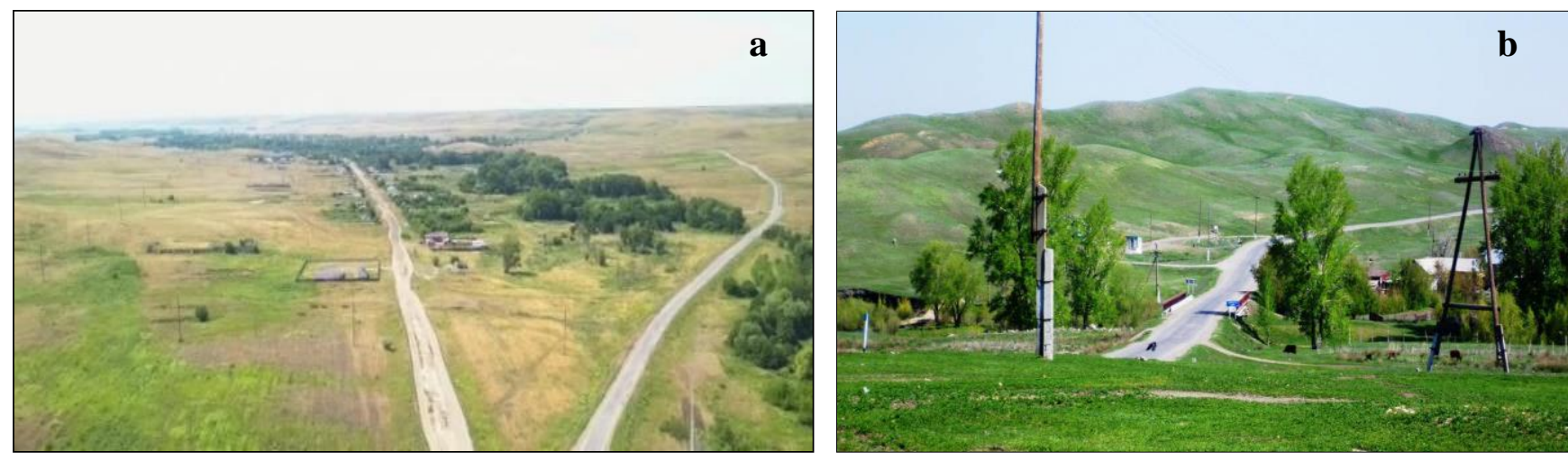

Figure 3. Settlements near the study area (photo of the author from a quadrocopter); a - Locality S. Kosistek; b - Locality S. Shamshi Kaldayakova

The level of nutrition corresponds to rural areas (natural products, which is important). However, near natural and recreational resources, infrastructure like seasonal rest homes, food outlets, etc. is completely lacking.

3.4 The information support block. On this point, we gave 1 point, since there is no information support; there is no publicity covering the beauty of nature. Information is distributed only through the local population (fishermen, hunters, etc.). In order to improve the information support, local authorities are recommended to develop infrastructure for seasonal tourism. Organizing beach places, putting various cafeterias, places for overnight stays and family holidays for summer and organizing skiing, sledding on hilly terrain and an ice rink on a pond for winter activities would transform infrastructure and therefore info support. It is also necessary to engage the local population for the development of cultural crafts and trade (local agricultural products, etc.).

\section{CONCLUSION}

The assessment of recreational resources for the development of tourism is carried out by experimental means. A particular difficulty in evaluating recreational resources lies in the fact that they must be considered both from the perspective of recreation organizers and from the perspective of vacationers. Thus, we have created an information block on the assessment of recreational potential. The final score is 2.1 (Table 1.). If we look at blocks $1-3$, then block 1 
"natural landscape potential" received the highest score. The "infrastructure" block got the lowest one. This suggests that having such a natural resource potential, it is necessary to improve human and infrastructural potential.

Funding: The given research was carried out within the framework of a project funded by the Science Committee of the Ministry of Education and Science of the Republic of Kazakhstan (Grant No. AP08856347).

\section{REFERENCES}

Akhmedenov, K.M. (2020). Tourist and recreational potential of the salt lakes of Western Kazakhstan. GeoJournal of Tourism and Geosites, 30(2spl), 782-787. https://doi.org/10.30892/gtg.302spl01-505

Akhmedenov, K., Petrishchev, V., Noreika, S., \& Ramazanov, S. (2017). Perspektivy sozdaniya osobo ohranyayemoi pripodnoi territorii "Gora Maloye Bogdo" [Prospects for the creation of a specially protected natural area "Mount Maloe Bogdo"]. Voprosy geografii i geoekologii (Geography and Geoecology), 3, 3-18, (in Russian).

Beketova, A., Berdenov, Z., Mendybayev, E., Safarov, R., Shomanova, Z., \& Herman, G.V. (2019). Geochemical monitoring of industrial center for development of recreational areas (on the example of Khromtau-Don industrial hub, Kazakhstan). GeoJournal of Tourism and Geosites, 27(4), 1449-1463. https://doi.org/10.30892/gtg.27428-447

Berdenov, Z.G., Atasoy, E., Mendybayev E., Ataeva G., \& Wendt, J.A. (2016). Geosystems geoecological assessment of the basin of rivers for tourist valorization case study of Ilek river basin. GeoJournal of Tourism and Geosites, Romania, 2(18), 187-195.

Berdenov, Z.G., \& Zhakupov, A.A. (2018). Transformation of methods for assessing the recreational potential at the first stage of tourism development in the region. Materialien der internationalen wissenschaftlichen Konferenz, Leipzig, DARA, 38-44, (in Russian).

Berdenov, Z., Mendibaev, E., Salihov, T., Akhmedenov, K., \& Ataeva, G. (2017). Geoecological analysis of industrial cities: On the example of Aktobe agglomeration. Chemistry, 26(6), 890-902.

Berdenov, Z.G., Dzhanaleeva, G.M., \& Shorabaeva, N.S. (2015). Prospects for the development of recreational activities in the Ilek river basin. Bulletin of KazNTU. Earth Science Series, Almaty, KazNTU, 4(110), 13-19, (in Russian).

Carretero, M.I., Pozo, M., Legido, J.L., Fernández-González, M.V., Delgao, R., Gómez, I., Armijo, F., \& Maraver, F. (2014). Assessment of three Spanish clays for their use in pelotherapy. Applied clay science, 99, 131- 143. http://dx.doi.org/10.1016/j.clay.2014.06.022

Datta, B. (2020). Factors affecting the satisfaction level of medical tourists: a case study of Delhi National Capital region. GeoJournal of Tourism and Geosites, 29(2), 628-635. https://doi.org/10.30892/gtg.29219-494

Deac, L.A., Gozner, M., \& Sambou, A. (2019). Ethnographic museums in the rural areas of Crișana Region, Romania - Keepers of local heritage, tradition and lifestyle. GeoJournal of Tourism and Geosites, 27(4), 1251-1260. https://doi.org/10.30892/gtg.27411-430

Dunets, A., Muhamedieva, A., Sycheva, I., Perepechkina, E., Vakhrushev, I., \& Kulchytskiy, A. (2019). Spatial tourism planning: Using the model of functional and planning complexes. Journal of Environmental Management and Tourism, 10(4), 711-719. https://doi.org/10.14505/jemt.v10.4(36).01

Dunets, A.N., Zhogova, I.G., \& Sycheva, I.N. (2019). Common characteristics in the organization of tourist space within mountainous regions: Altaisayan region (Russia). GeoJournal of Tourism and Geosites, 24(1), 161-174. https://doi.org/10.30892/gtg.24113-350

Egorina, A.V., Kaliakperova, N.Z., \& Kanatkyzy, N. (2016). Recreational opportunities of East Kazakhstan for tourism development. International Journal of Applied and Fundamental Research, 3, 298-302.

Erdavletov, S.R. (2010). Tourism history. Development and scientific study. Almaty: Atamura, 336, (in Russian).

Herman, G.V., Wendt, A.J., Dumbravă, R., \& Gozner, M. (2019). The role and importance of promotion centers in creating the image of tourist destination: Romania. Geographia Polonica, 92(4), 443-454. https://doi.org/10.7163/GPol.0158

Indrie, L., Zlatev, Z., Ilieva, J., Ilies, D.C., Sturza, A., Dochia, M., Gozner, M., Herman, G., Caciora, T. (2020). Implementation of image processing techniques as a tool for form analysis of Romanian folk elements. Industria textila, 71(5), 492-498. http://doi.org/10.35530/IT.071.05.1690

Ilies, A., Hurley, P.D., Ilies, D.C., \& Baias, S. (2017). Tourist animation -a chance adding value to traditional heritage: case studys in the Land of Maramures (Romania). Revista de Etnografie si Folclor, 1-2(1-2), 131-151.

Ilies, A., \& Grama, V. (2010). The external western balkan border of the European Union and its borderland: premises for building functional transborder territorial systems. Annales-Anali za Istrske in Mediteranske Studije-Series Historia et Sociologia, 20(2), $457-468$.

Isachenko, A.G. (2008). Landscape structure of the Earth, resettlement, nature management. St. Petersburg State University, 320, (in Russian).

Jackson, J., \& Murphy, P. (2002). Tourism Destinations as Clusters: Analytical experiences from the New Word. Tourism and Hospitality Research, 4(1), 36-52.

Khomitch, S., Ramanchuk, A., Daniltchenko, A., \& Rzętała, M. (2019). Key factors for tourist and recreational use of quarry ponds of Belarus and Poland. GeoJournal of Tourism and Geosites, 27(4), 1114-1133. https://doi.org/10.30892/gtg.27401-420

Kuskov, A.S., Odintsova, T.N., Golubeva, V.L. (2005). Recreational geography. M. Flint, 493, (in Russian).

Marcu, F., Ilies, D.C., Wendt, J., Indrie, L., Ilies, A., Burta, L., Caciora, T., Herman, G.V., Todoran, A., Baias, S., Albu, A., \& Gozner, M. (2020). Investigations Regarding the Biodegradation of Cultural Heritage. Case Study of Traditional Embroidered Peasent Shirt (Maramures, Romania). Biothnological Letter, 25(2), 1362-1368. https://www.e-repository.org/rbl/vol.25/iss.2/8.pdf

Nazarova, T.V., Fomin, I.A., Dmitriev, P.S., Wendt, J.A., \& Janaleyeva, K.M. (2019). Landscape and limnological research of lake systems of the plain areas of the northeastern borderlands of the Republic of Kazakhstan and assessment of their recreational capacity. GeoJournal of Tourism and Geosites, 25(2), 485-495. https://doi.org/10.30892/gtg.25217-375

Page, S. (2011). Tourism management. Oxon: Routledge Advances in Tourism, England.

Sokolova, M.V. (2004). History of tourism. M.V. Sokolov. M. Academy, (in Russian).

Suleimenov, I., Bakirov A., Niyazova G., \& Shaltykova D. (2021). University as an analogue of the neural network. E3S Web Conf., 258 (07056). https://doi.org/10.1051/e3sconf/202125807056

Suleimenov, I., Egemberdieva, Z., Bakirov, A., Baipakbayeva, S., Kopishev, E., \& Mun, G. (2020). Efficiency Problem of renewable energetics systems in the context of a «smart house» concept. E3S Web of Conferences, 5 May 2020, 164.

Vilesov, E., Naumenko, A., Veselova, L., \& Aubekerov, B. (2009). Phizicheskaya geographiay Kazahstana [Physical geography of Kazakhstan]. Edited by Vilesov, E., Naumenko, A., Veselova, L., Aubekerov B. Almaty: Kazakh University, Kazakhstan, (in Russian).

** SASPlanet (2021). Online resource. http://sasgis.ru/sasplaneta/

*** GISMETEO Directory (2020). Online resource Meteorological station Kos-Istek. https://www.gismeteo.ru/weather-kos-istek-296812/ 